\title{
Phosphorus Removal from Wastewater Using Oven-Dried Alum Sludge
}

\author{
Wadood T. Mohammed and Sarmad A. Rashid \\ Chemical Engineering Department, College of Engineering, University of Baghdad, Baghdad, Iraq \\ Correspondence should be addressed to Sarmad A. Rashid, sermed1972@yahoo.com
}

Received 24 January 2012; Accepted 14 May 2012

Academic Editor: See-Jo Kim

Copyright ( $) 2012$ W. T. Mohammed and S. A. Rashid. This is an open access article distributed under the Creative Commons Attribution License, which permits unrestricted use, distribution, and reproduction in any medium, provided the original work is properly cited.

\begin{abstract}
The present study deals with the removal of phosphorus from wastewater by using oven-dried alum sludge (ODS) as adsorbent that was collected from Al-Qadisiya treatment plant (Iraq); it was heated in an oven at $105^{\circ} \mathrm{C}$ for $24 \mathrm{~h}$ and then cooled at room temperature. The sludge particles were then crushed to produce a particle size of $0.5-4.75 \mathrm{~mm}$. Two modes of operation are used, batch mode and fixed bed mode, in batch experiment the effect of oven-dried alum sludge doses 10-50 g/L, pH of solution 5-8 with constant initial phosphorus concentration of $5 \mathrm{mg} / \mathrm{L}$, and constant particle size of $0.5 \mathrm{~mm}$ were studied. The results showed that the percent removal of phosphorus increases with the increase of oven-dried alum sludge dose, but $\mathrm{pH}$ of solution has insignificant effect. Batch kinetics experiments showed that equilibrium time was about 6 days. Adsorption capacity was plotted against equilibrium concentration, and isotherm models (Freundlich, Langmuir, and Freundlich-Langmuir) were used to correlate these results. In the fixed bed isothermal adsorption column, the effect of initial phosphorus concentration $\left(C_{o}\right) 5$ and $10 \mathrm{mg} / \mathrm{L}$, particle size 2.36 and $4.75 \mathrm{~mm}$, influent flow rate $(Q) 6$ and $10 \mathrm{~L} / \mathrm{hr}$, and bed depth $(H) 0.15-0.415 \mathrm{~m}$ were studied. The results showed that the oven-dried alum sludge was effective in adsorbing phosphorus, and percent removal of phosphorus reaches $85 \%$ with increasing of contact time and adsorbent surface area (i.e., mass of adsorbent $50 \mathrm{~g} / \mathrm{L}$ with different $\mathrm{pH}$ ).
\end{abstract}

\section{Introduction}

Wastewater or contaminated water is a big environmental problem all over the world, in industrial plants; contaminants may be a result of side reactions, rendering the water stream an effluent status. These impurities are at low-level concentration but still need to be further reduced to levels acceptable by various destinations in the plant. Surface waters contain certain level of phosphorus (P) in various compounds, which is an important constituent of living organisms. In natural conditions the phosphorus concentration in water is balanced; that is, accessible mass of this constituent is close to the requirements of the ecological system. When the input of phosphorus to water is higher than it can be assimilated by a population of living organisms, the problem of excess phosphorus content occurs. Regulatory control on phosphorus disposal is evident all over the world recently [1-3]. Strict regulatory requirements decreased the permissible level of phosphorus concentration in wastewater at the point of disposal (i.e.,
$1 \mathrm{mg} / \mathrm{L})$. This has made it very important to find appropriate technological solution for treatment of wastewater prior to disposal.

Phosphorus removal is considered as a major challenge in wastewater treatment, particularly for small-scale wastewater treatment systems. Processes available for P-treatment are generally classified into three general categories: chemical, physical, or biological-based treatment systems. Among physical-chemical methods, phosphorus removal is achieved using ion exchange $[4,5]$, dissolved air flotation $[6,7]$, and membrane filtration $[8,9]$. Filtration has been used either alone or in conjunction with a coagulation process as a means to remove phosphorus from wastewater $[10,11]$. High-rate sedimentation has also been attempted in some studies $[12,13]$. Among the various physical-chemical methods, coagulation with chemical precipitation and adsorption are the most common techniques being used for removing phosphorus. Enhanced biological methods for removing phosphorus are also used with success $[14,15]$. For smallscale applications (e.g., aquaculture) biological methods may 
not be appropriate for phosphorus removal because of the low carbon concentrations, which increases cost and time involved in biological methods [16]. Alternatively, physicalchemical methods can offer advantages for small industries because of lower initial costs involvement. These methods are also easier to use and do not require high level of expertise to maintain. Physical-chemical methods can also accommodate recycling sludge to reduce further costs involved in handling sludge. However, finding an effective and feasible material is a significant challenge in physical-chemical approach. This problem has not been addressed so far as a complete solution. The key problem is to find a suitable material, which is easily available and effective to remove phosphorus from smallscale wastewater applications.

Biosolid management is considered very important, as there are considerable amounts of biosolids generated due to anthropogenic reasons. Alum sludge, a biosolid generated in the coagulation process in a water treatment plant, is one such type.

Divalent and trivalent cation-based materials are known to be effective for phosphorus removal. Therefore, aluminum-based residuals (i.e., alum sludge) are a viable option for being an effective phosphorus removal material. Alum is typically effective in phosphorus removal in chemical precipitation process [17]. Therefore, use of alum sludge can be effective for phosphorus removal. Air-dried alum sludge has also been attempted in limited manner by some researchers with success [18]. However, the use of waste material (alum sludge) not only can provide lowcost appropriate technological alternative for small-scale applications but also reduce hazard and cost related to the disposal of large amount of alum sludge.

The aim of this work was to investigate the effectiveness of oven-dried alum sludge for adsorption of orthophosphate from deionized water and to compare the results with other conventional adsorbent (i.e., activated carbon).

1.1. Adsorption Isotherm. The most common forms of adsorption isotherms used in chemical-environmental engineering are the Langmuir and the Brunauer, Emmett and Teller (BET) besides the Freundlich empirical model [1923]. The Langmuir model can be described as

$$
\frac{X}{m}=\frac{\left(a b C_{e}\right)}{\left(1+a C_{e}\right)},
$$

where $X=$ mass of solute adsorbed to the solid (mg), $m=$ mass of adsorbent used ( $\mathrm{g}), C_{e}=$ concentration of solute in solution at equilibrium $(\mathrm{mg} / \mathrm{L}), a=$ Langmuir constant; the amount of solute adsorbed per unit weight of an adsorbent in forming a complete monolayer $(\mathrm{L} / \mathrm{mg}), b=$ Langmuir constant (mg/g).

Assumptions made in developing the Langmuir model are as follows [19].

(a) The maximum adsorption corresponds to a saturated monolayer of solute molecules on the adsorbent surface.

(b) The energy of adsorbent is constant. (c) There is no transmigration of adsorbate in the plane of the surface.

(d) The adsorption is reversible.

The Freundlich isotherm is an empirical model and was developed for heterogeneous surfaces. The Freundlich adsorption model is of the form [19]

$$
\frac{X}{m}=k C_{e}^{1 / n}
$$

where $k=$ Freundlich equilibrium constant indicative of adsorptive capacity, $n=$ Freundlich constant indicative of adsorption intensity.

Combination of Langmuir-Freundlich isotherm model, that is, the SIPS model for single component adsorption [24] is

$$
q_{e}=\frac{\left(b q m C_{e}{ }^{1 / n}\right)}{\left(1+b C_{e}^{1 / n}\right)} .
$$

The BET isotherm model is of the form

$$
\frac{X}{m}=\frac{\left(A C_{e} X_{m}\right)}{\left[\left(C_{s}-C_{e}\right)\left\{1+(A-1)^{C_{e} / C_{s}}\right\}\right]},
$$

where $A=$ a constant describing energy interaction between the solute and the adsorbent surface, $X_{m}=$ amount of solute adsorbed in forming a complete monolayer $(\mathrm{M} / \mathrm{M}), C_{e}=$ concentration of solute in solution at equilibrium, $C_{s}=$ saturation concentration of solute in solution.

The BET isotherm model has been developed on the following assumptions [19].

(a) The model describes multilayer adsorption at the adsorbent surface.

(b) The Langmuir model applies to each layer.

(c) A given layer needs not complete formation prior to initiation of subsequent layers.

\section{Experimental}

2.1. Alum Sludge. Alum sludge is a waste material generated during the coagulation/sedimentation process in a drinking water treatment plant. Inorganic materials in alum sludge are presented in Table 1.

Alum sludge used in this research was heated in an oven at $105^{\circ} \mathrm{C}$ for 24 hours. The dried sludge was then cooled to room temperature. The sludge particles were then crushed to produce a particle size of $(0.5,2.36$, and 4.75$) \mathrm{mm}$. The physical properties are listed in Table 2.

2.2. Granulated Activated Carbon (GAC). Granulated activated carbon (GAC) is one of the most widely used adsorbents for organic, metallic, and inorganic contaminants in water. It was supplied by Unicarbo, Italians to the Iraqi local markets. The physical properties are listed in Table 3 [25].

2.3. Adsorbate. Orthophosphate (potassium dihydrogen orthophosphate $\mathrm{KH}_{2} \mathrm{PO}_{4}$ ) was used to prepare a phosphorus solution. Orthophosphate was chosen as it is the key species of phosphorus in most wastewaters. The physical properties of $\mathrm{KH}_{2} \mathrm{PO}_{4}$ are listed in Table 4. 
TABLE 1: Inorganic materials in alum sludge.

\begin{tabular}{lc}
\hline Constituent & Weight percent \\
\hline Aluminum & $3.38 \%$ \\
Iron & $0.819 \%$ \\
Manganese & $0.16 \%$ \\
Chromium & $0.013 \%$ \\
Vanadium & $0.002 \%$ \\
Zinc & $0.0098 \%$ \\
Lead & $0.0001 \%$ \\
Barium & $0.0001 \%$ \\
Arsenic & $0.0002 \%$
\end{tabular}

TABLe 2: Physical properties of oven dried alum sludge.

\begin{tabular}{lc}
\hline Item name & Oven dried alum sludge \\
\hline Bulk density $\left(\mathrm{kg} / \mathrm{m}^{3}\right)$ & 786.7 \\
Particle porosity & 0.7 \\
Bed porosity & 0.65 \\
BET surface area $\left(\mathrm{m}^{2} / \mathrm{g}\right)$ & 191 \\
\hline
\end{tabular}

TABLe 3: Physical properties of activated carbon.

\begin{tabular}{lc}
\hline Item name & Granulated activated carbon \\
\hline Base & Coconut shell \\
Apparent density $\left(\mathrm{kg} / \mathrm{m}^{3}\right)$ & $480-490$ \\
Bulk density $\left(\mathrm{kg} / \mathrm{m}^{3}\right)$ & 770 \\
BET surface area $\left(\mathrm{m}^{2} / \mathrm{g}\right)$ & 1000 \\
Particle porosity & 0.5 \\
Bed porosity & 0.4 \\
Ash content $(\%)$ & $5(\max )$ \\
Iodine number $(\mathrm{mg} / \mathrm{g})^{*}$ & $1100-1130$ \\
pH** & $10.2-10.6$ \\
\hline
\end{tabular}

${ }^{*}$ The iodine number refers to the milligrams of a 0.02 normal iodine solution per gram of GAC during a standard test (ASTM D4607).

**The $\mathrm{pH}$ of a solution of distilled water with a specific dosage of GAC according to a standard test (ASTM D3838).

TABLE 4: Main properties of adsorbate.

\begin{tabular}{lc}
\hline Name of component & Potassium dihydrogen orthophosphate \\
\hline $\begin{array}{l}\text { Chemical symbol } \\
\text { Name of company }\end{array}$ & $\mathrm{KH}_{2} \mathrm{PO}_{4}$ \\
Molecular weight & $136.09 \mathrm{~kg} / \mathrm{kg} \cdot$ mole \\
Assay (acidimetric) & 99 to 101 per cent \\
Chloride $(\mathrm{Cl})$ & Not more than 0.01 per cent \\
Sodium $(\mathrm{Na})$ & Not more than 0.2 per cent \\
Sulphate $\left(\mathrm{SO}_{4}\right)$ & Not more than 0.05 per cent \\
pH $(1$ percent solution $)$ & 4.5 to 4.7 \\
\hline
\end{tabular}

2.4. Wastewater. Deionized water was spiked with $\mathrm{KH}_{2} \mathrm{PO}_{4}$ to prepare a phosphorus solution of (5 and 10$) \mathrm{mg} / \mathrm{L}$; the masses used are listed in Table 5. The phosphorus concentration was chosen as typical phosphorus concentration in many wastewaters.
TABle 5: Phosphorus solution.

\begin{tabular}{lc}
\hline Phosphorus concentration $(\mathrm{mg} / \mathrm{L})$ & $\mathrm{KH}_{2} \mathrm{PO}_{4}$ to be added $(\mathrm{g})$ \\
\hline 5 & 0.00715 \\
10 & 0.0143 \\
\hline
\end{tabular}

2.5. Adsorption Column. The fixed bed adsorber studies were carried out in Q.V.F. glass column of 2 in. (50.8 mm) I.D. and (30 and 50$) \mathrm{cm}$ in height.

The oven-dried alum sludge was confined in the column by fine stainless steel screen at the bottom and a glass cylindrical packing at the top of the bed to ensure a uniform distribution of influent through the alum sludge. The influent solution was introduced to the column through a perforated plate, fixed at the top of the column.

2.6. Experimental Arrangements. The schematic representation of experimental equipment is shown in Figure 1.

\section{Experimental Work}

3.1. Batch Experiments. Batch experiments were used to obtain the equilibrium isotherm curves and then the equilibrium data. In batch mode the following experiments were carried out:

(i) effect of oven-dried alum sludge weight on adsorption process,

(ii) effect of $\mathrm{pH}$ of solution on adsorption process,

(iii) equilibrium isotherm experiments.

All experiments were carried out at $25^{\circ} \mathrm{C} \pm 1$. The desired $\mathrm{pH}$ was adjusted using $0.1 \mathrm{M} \mathrm{NaOH}$ and $\mathrm{HCl}$.

Five $1 \mathrm{~L}$ flasks were used for each $\mathrm{pH}$ solution (i.e., 5, 6, 7, and 8). For experiments conducted with an initial phosphorus concentration of $5 \mathrm{mg} / \mathrm{L}$, alum sludge was used in concentration of $(10,20,30,40$ and 50) g/L. Samples were collected from the flasks and after 7.5 days tested for total orthophosphate phosphorus concentration. Phosphorus that was lost from the solution was assumed to be adsorbed onto the adsorbents. Data obtained from batch tests conducted on deionized water fitted to Freundlich, Langmuir, and Freundlich-Langmuir adsorption isotherm equations.

3.2. Fixed Bed Column Experiments. Column experiments were carried out to measure the breakthrough curves for the systems. Experiments were carried out at various $\mathrm{pH}$, initial phosphorus concentrations $\left(C_{o}\right)$, particle size, flow rate $(Q)$, and bed depth $(H)$.

\section{Results}

\subsection{Batch Experiments}

4.1.1. Effect of Mass of Oven-Dried Alum Sludge on the Adsorption Process. The results of the dependence of phosphorus on the mass of oven-dried alum sludge of size $0.5 \mathrm{~mm}$ at $25^{\circ} \mathrm{C}$ 


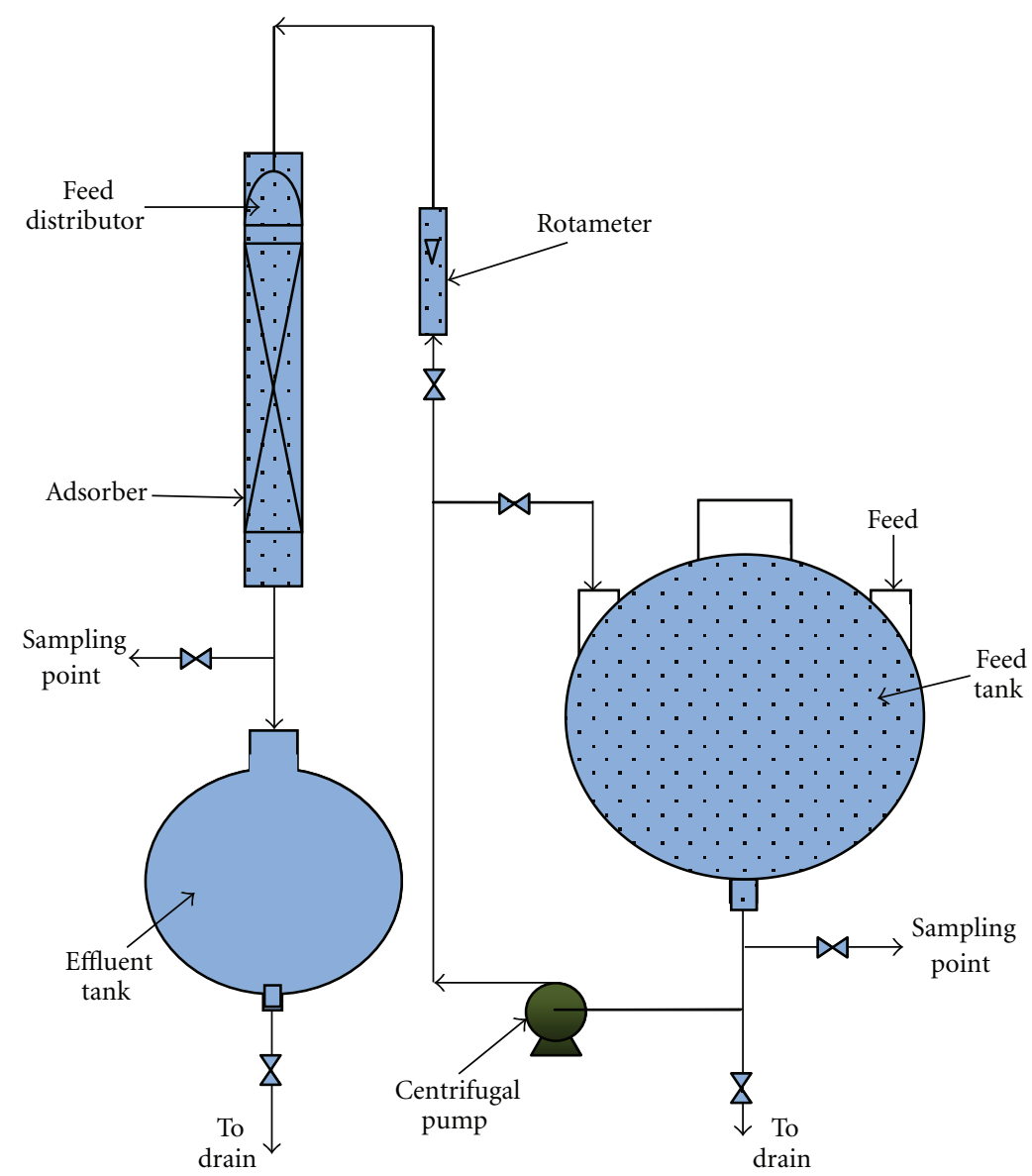

FIGURE 1: Schematic representation of experimental equipment.

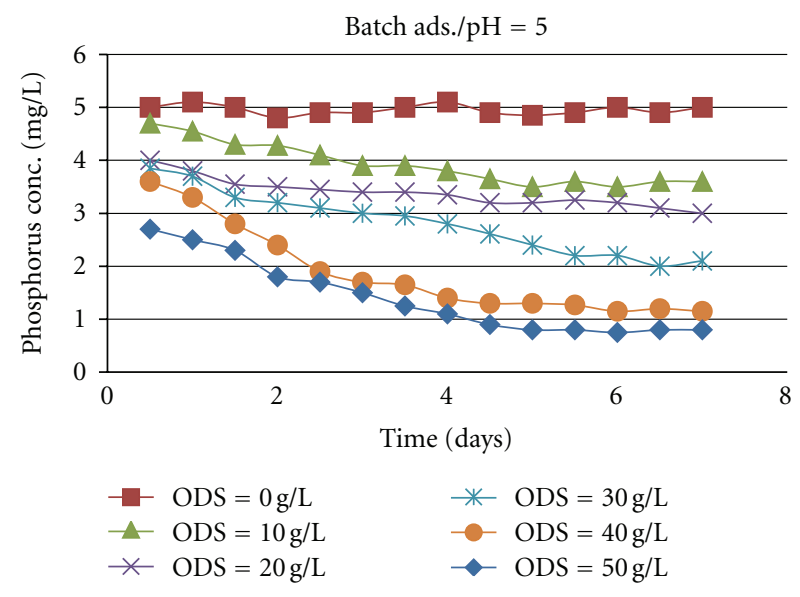

FIGURE 2: Change in phosphorus concentration with time of batch tests $\left(C_{o}=5 \mathrm{mg} / \mathrm{L}, \mathrm{pH}=5\right.$, Temp. $=25^{\circ} \mathrm{C}$, particle size $\left.=0.5 \mathrm{~mm}\right)$.

are shown in Figures 2, 3, 4, 5, 6, 7, 8, and 9. These figures represent the plotting of the phosphorus concentration with time and the percentage removal of phosphorus against the mass of oven-dried alum sludge, respectively.

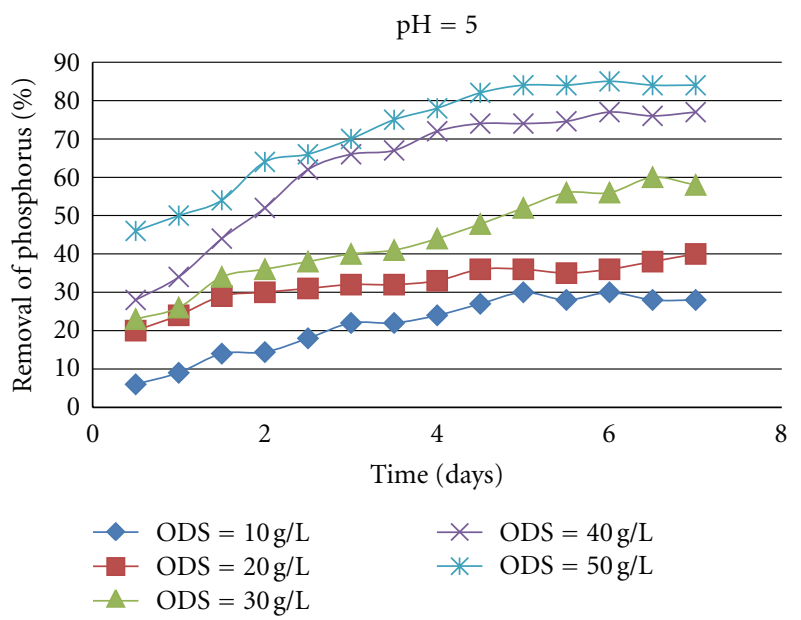

Figure 3: The effect of ODS on phosphorus removal $\left(C_{o}=5 \mathrm{mg} / \mathrm{L}\right.$, $\mathrm{pH}=5$, Temp. $=25^{\circ} \mathrm{C}$, particle size $=0.5 \mathrm{~mm}$ ).

The percent removal of phosphorus increases with increasing weight of oven-dried alum sludge up to a certain value depending on adsorption sites. These figures can clearly show that the increase in the percent removal of phosphorus 


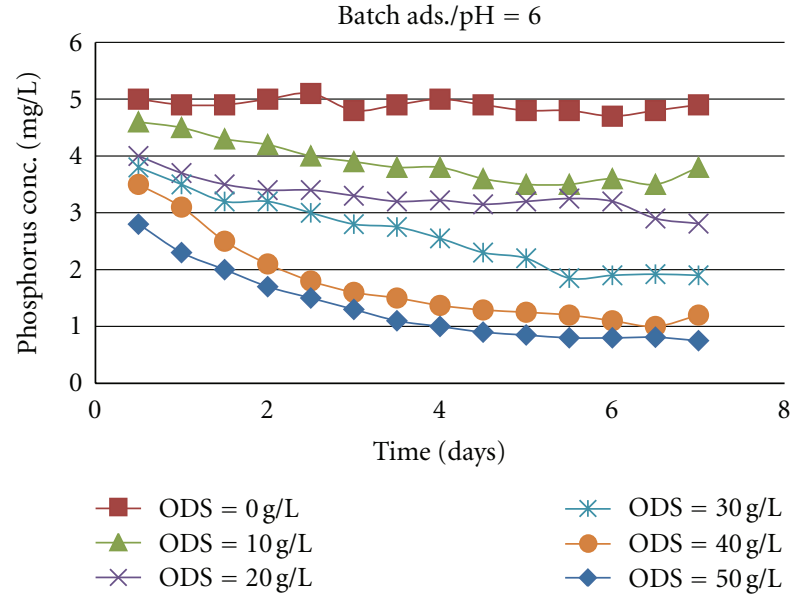

FIGURE 4: Change in phosphorus concentration with time of batch tests $\left(C_{o}=5 \mathrm{mg} / \mathrm{L}, \mathrm{pH}=6\right.$, Temp. $=25^{\circ} \mathrm{C}$, particle size $\left.=0.5 \mathrm{~mm}\right)$.

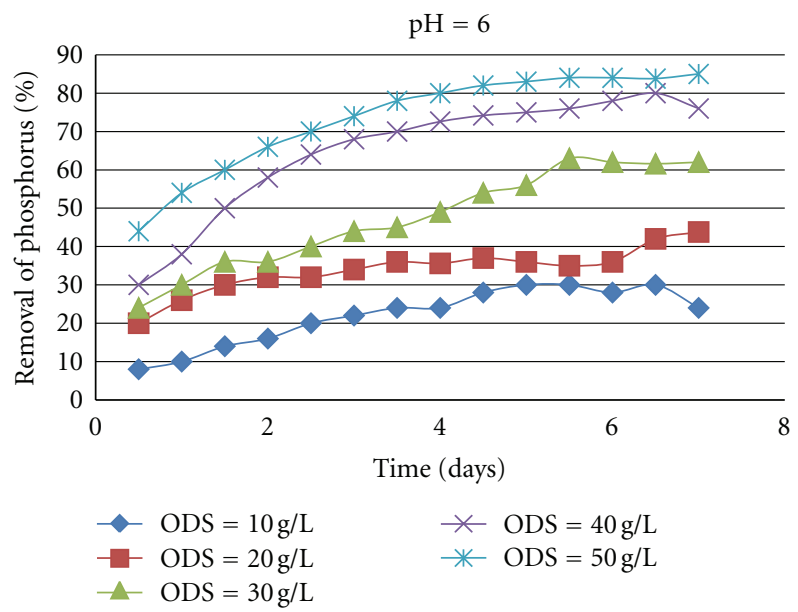

FIgURE 5: The effect of ODS on phosphorus removal $\left(C_{o}=5 \mathrm{mg} / \mathrm{L}\right.$, $\mathrm{pH}=6$, Temp. $=25^{\circ} \mathrm{C}$, particle size $=0.5 \mathrm{~mm}$ ).

Batch ads. $/ \mathrm{pH}=7$

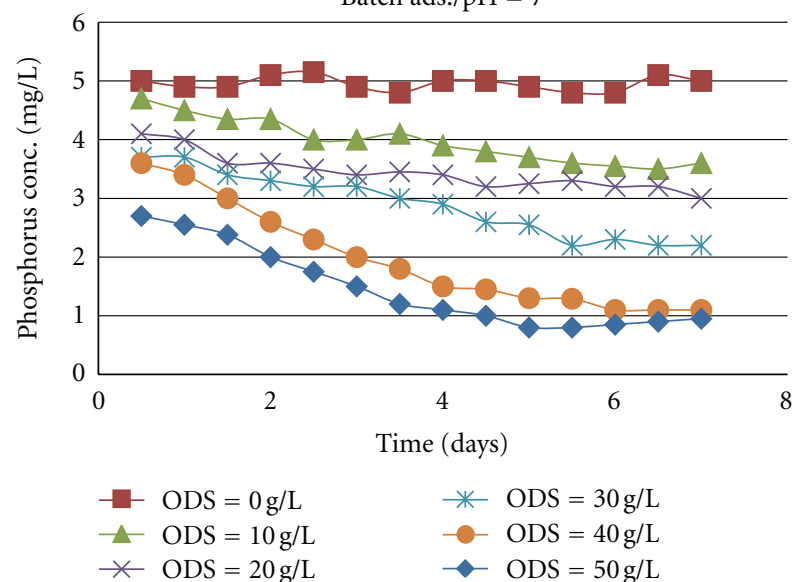

FIGURE 6: Change in phosphorus concentration with time of batch tests $\left(C_{o}=5 \mathrm{mg} / \mathrm{L}, \mathrm{pH}=7\right.$, Temp. $=25^{\circ} \mathrm{C}$, particle size $\left.=0.5 \mathrm{~mm}\right)$.
$\mathrm{pH}=7$

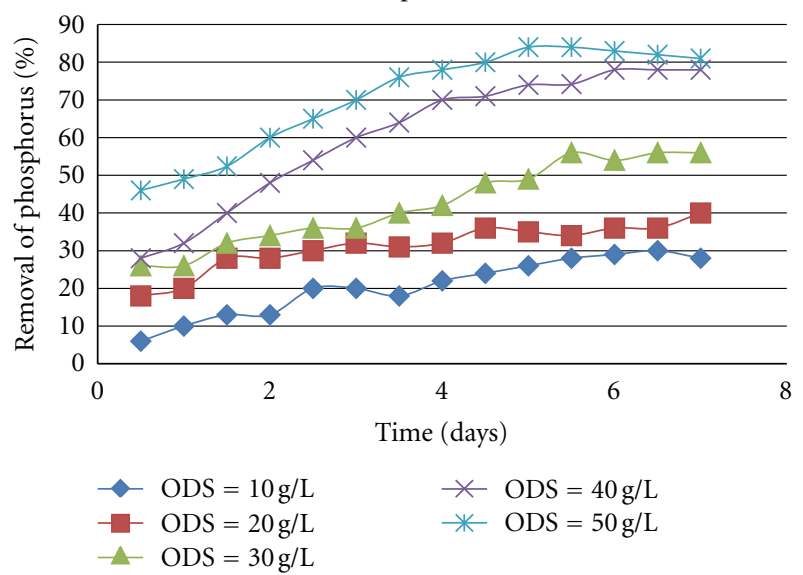

FIGURE 7: The effect of ODS on phosphorus removal $\left(C_{o}=5 \mathrm{mg} / \mathrm{L}\right.$, $\mathrm{pH}=7$, Temp. $=25^{\circ} \mathrm{C}$, particle size $=0.5 \mathrm{~mm}$ ).

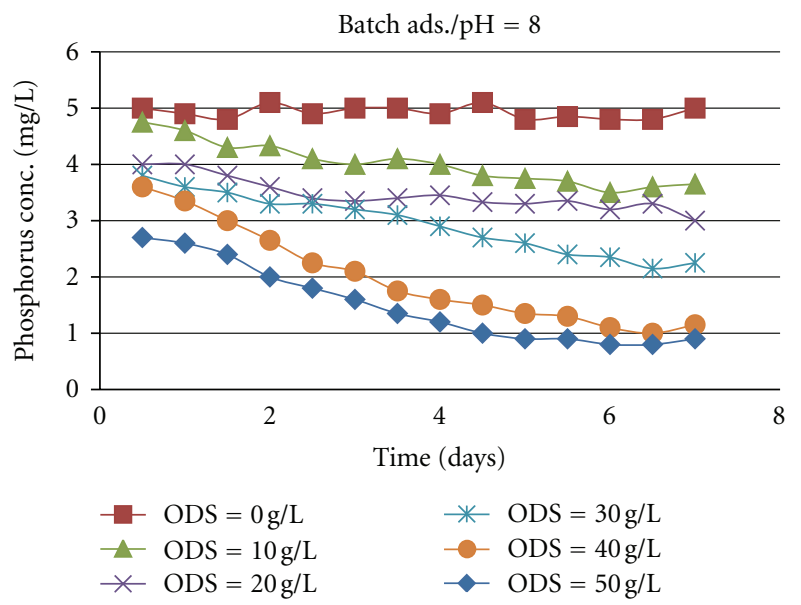

FIGURE 8: Change in phosphorus concentration with time of batch tests $\left(C_{o}=5 \mathrm{mg} / \mathrm{L}, \mathrm{pH}=8\right.$, Temp. $=25^{\circ} \mathrm{C}$, particle size $\left.=0.5 \mathrm{~mm}\right)$.

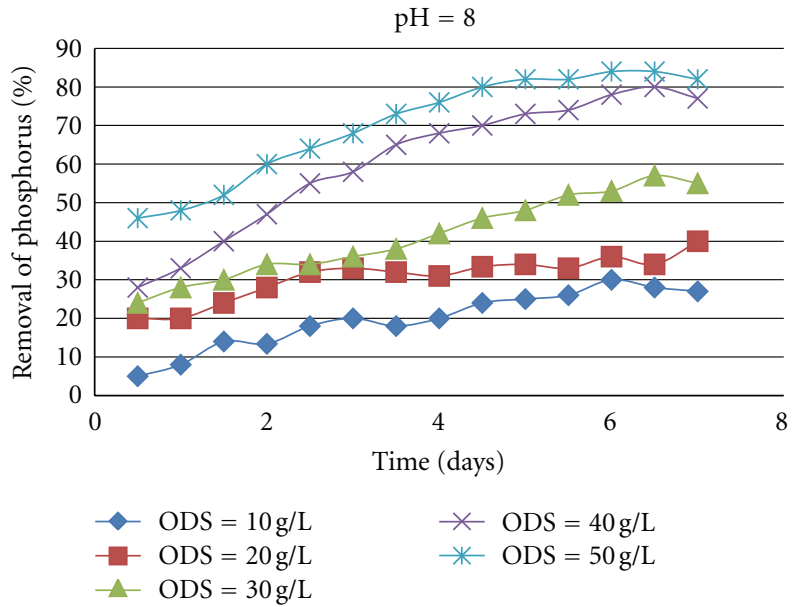

FIgure 9: The effect of ODS on phosphorus removal $\left(C_{o}=5 \mathrm{mg} / \mathrm{L}\right.$, $\mathrm{pH}=8$, Temp. $=25^{\circ} \mathrm{C}$, particle size $=0.5 \mathrm{~mm}$ ). 


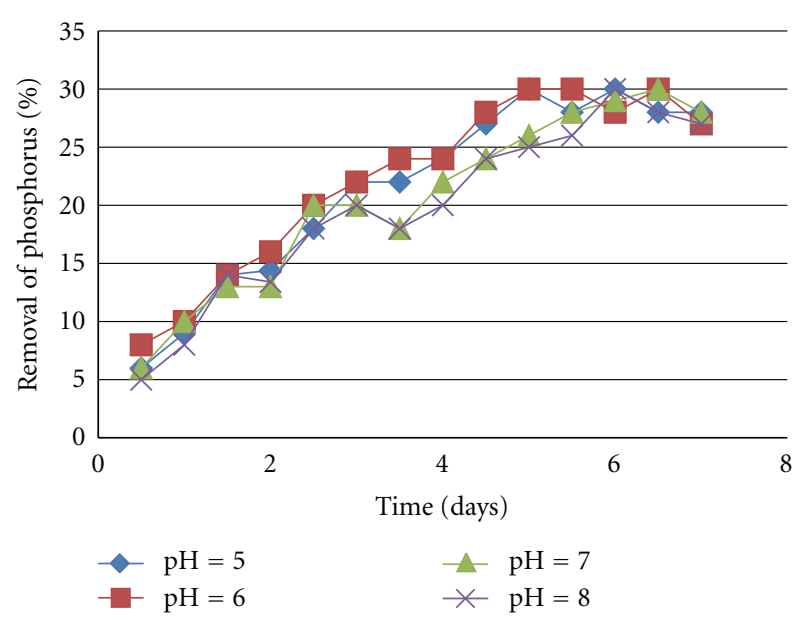

FIGURE 10: The effect of $\mathrm{pH}$ on adsorption of phosphorus by ODS $\left(C_{o}=5 \mathrm{mg} / \mathrm{L}\right.$, mass of sludge $=10 \mathrm{~g} / \mathrm{L}$, Temp. $\left.=25^{\circ} \mathrm{C}\right)$.

is due to the greater availability of adsorption sites or surface area of adsorbent (oven-dried alum sludge).

4.1.2. Effect of $p H$ on the Adsorption Process. The removal of phosphorus by using oven-dried alum sludge, as a function of $\mathrm{pH}$, is presented in Figures 10, 11, 12, 13, and 14. Effect of $\mathrm{pH}$, on the adsorption density is illustrated in Figure 15. $\mathrm{pH}$ had little effect on the adsorption density. However, solution $\mathrm{pH}$ of 6 appeared to produce maximum adsorption density in many of the experimental results.

The effluent $\mathrm{pH}$ was understandably dependent on the influent $\mathrm{pH}$. An influent $\mathrm{pH} 5$ produced effluent $\mathrm{pH}$ of (4.75.5). Similarly an influent $\mathrm{pH} 6$ generated an effluent $\mathrm{pH}$ range (5.6-6.3), and an influent $\mathrm{pH} 7$ generated an effluent $\mathrm{pH}$ range of $(6.5-7.5)$. It was due to the adsorption and desorption of $\mathrm{H}^{+}$ions during the adsorption of phosphorus on alum sludge. An effluent pH below 4.5 is not suitable for disposal in surface water. The effluent $\mathrm{pH}$ can be increased prior to disposal in surface water. However, the cost of chemicals to reduce initial $\mathrm{pH}$ and to increase final $\mathrm{pH}$ and hazards of dealing with increased amount of sludge would pose negative interest for $\mathrm{pH}$ control.

In general, a $\mathrm{pH}$ value in the range of (6-9) is reasonable for wastewaters before disposal into surface water.

The removals of phosphorus on oven-dried alum sludge for all the pHs were more than (80)\%.

4.2. Equilibrium Isotherm Experiments. The adsorption isotherm curves were obtained by plotting the weight of the solute adsorbed per unit weight of the adsorbent $\left(q_{e}\right)$ against the equilibrium concentration of the solute $\left(c_{e}\right)$. Figures 16, 17, 18, and 19 show the adsorption isotherm curves for phosphorus adsorption onto oven-dried alum sludge at $25^{\circ} \mathrm{C}$. The obtained data of phosphorus was correlated with Langmuir, Freundlich, and Langmuir-Freundlich models. The parameters for each model were obtained from nonlinear statistical fit of the equation to the experimental

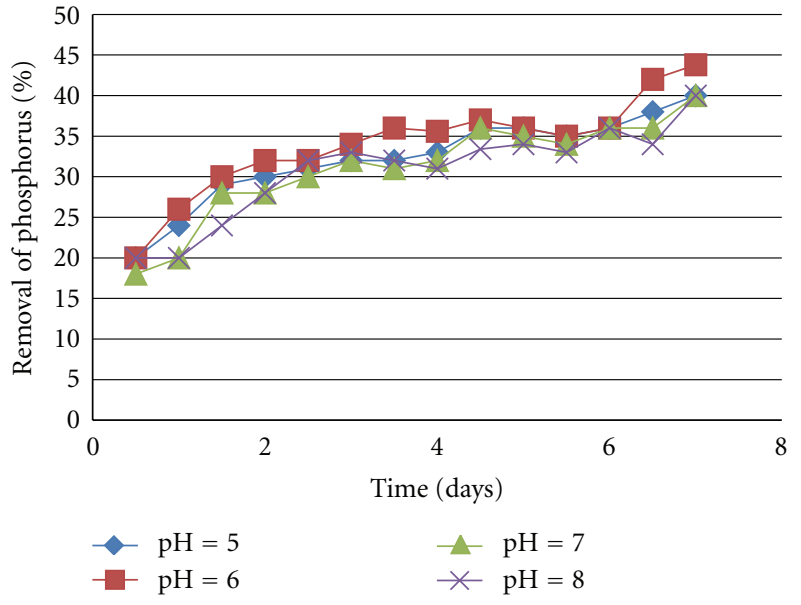

FIGURE 11: The effect of $\mathrm{pH}$ on adsorption of phosphorus by ODS $\left(C_{o}=5 \mathrm{mg} / \mathrm{L}\right.$, mass of sludge $=20 \mathrm{~g} / \mathrm{L}$, Temp. $\left.=25^{\circ} \mathrm{C}\right)$.

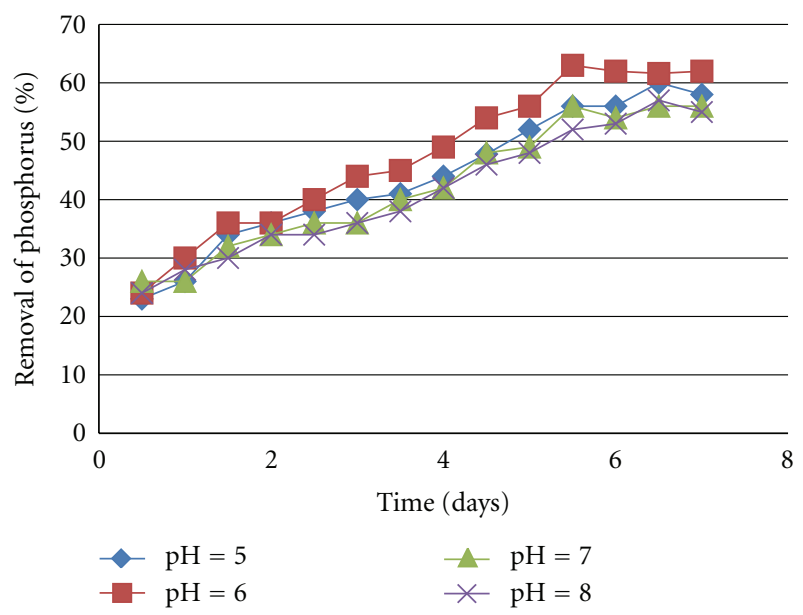

FIGURE 12: The effect of $\mathrm{pH}$ on adsorption of phosphorus by ODS $\left(C_{o}=5 \mathrm{mg} / \mathrm{L}\right.$, mass of sludge $=30 \mathrm{~g} / \mathrm{L}$, Temp. $\left.=25^{\circ} \mathrm{C}\right)$.

data. All parameters with their correlation coefficients $\left(R^{2}\right)$ are summarized in Table 6 .

It is clear from the previous figures and table the following.

(i) The equilibrium isotherm is of favorable type, for being convex upward.

In order to assess the different isotherms and their ability to correlate with experimental results, the correlation coefficient was employed to ascertain the fit of each isotherm with experimental data. From Table 6, the correlation coefficient value was higher for Langmuir-Freundlich than other correlations. This indicates that the Langmuir-Freundlich isotherm is clearly the best fitting isotherm to the experimental data. 


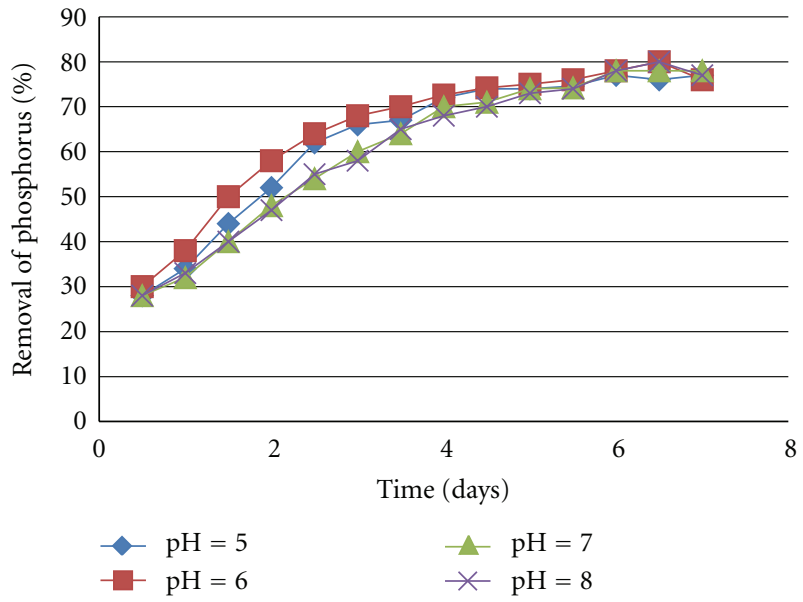

FIGURE 13: The effect of $\mathrm{pH}$ on adsorption of phosphorus by ODS $\left(C_{o}=5 \mathrm{mg} / \mathrm{L}\right.$, mass of sludge $=40 \mathrm{~g} / \mathrm{L}$, Temp. $\left.=25^{\circ} \mathrm{C}\right)$.

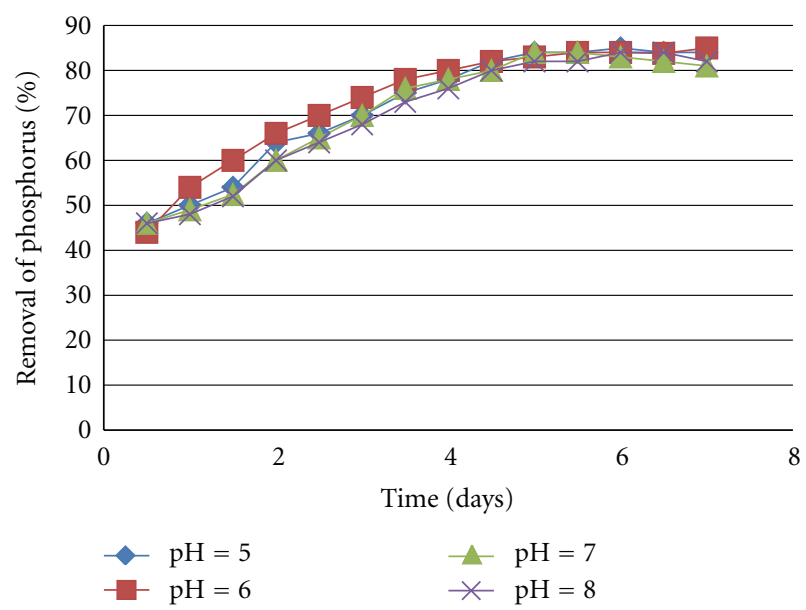

FIGURE 14: The effect of $\mathrm{pH}$ on adsorption of phosphorus by ODS $\left(C_{o}=5 \mathrm{mg} / \mathrm{L}\right.$, mass of sludge $=50 \mathrm{~g} / \mathrm{L}$, Temp. $\left.=25^{\circ} \mathrm{C}\right)$.

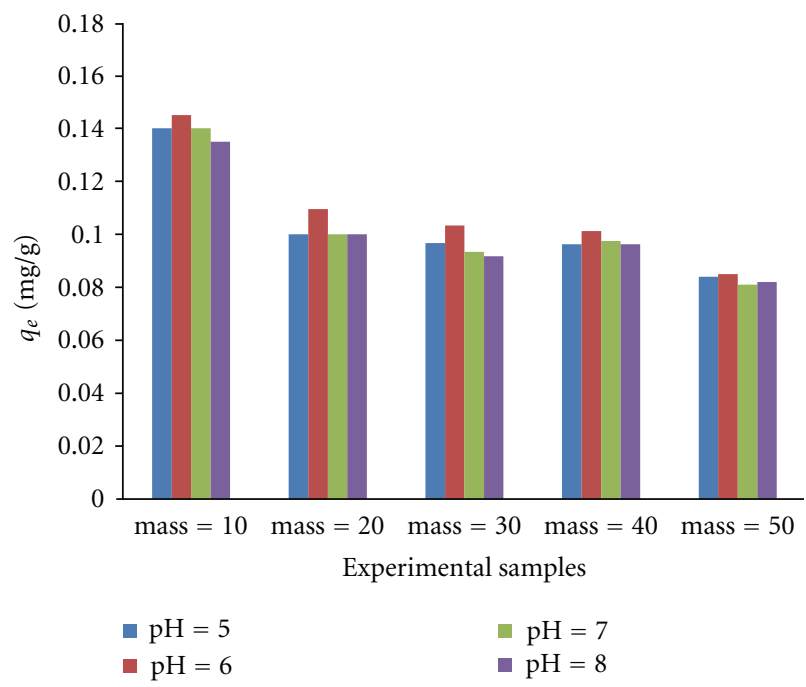

FIGURE 15: The effect of $\mathrm{pH}$ of solution on adsorption density.

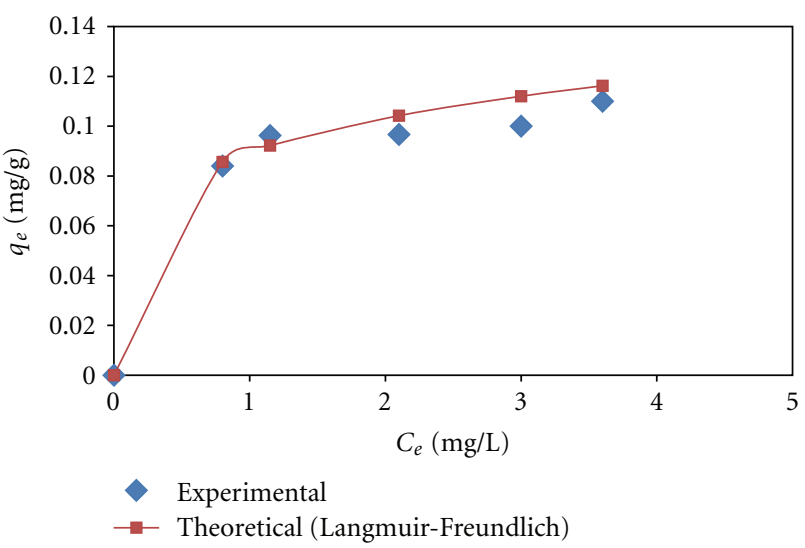

Figure 16: Adsorption isotherm for phosphorus onto ODS $\left(C_{o}=\right.$ $5 \mathrm{mg} / \mathrm{L}, \mathrm{pH}=5$, Temp. $=25^{\circ} \mathrm{C}$ ).

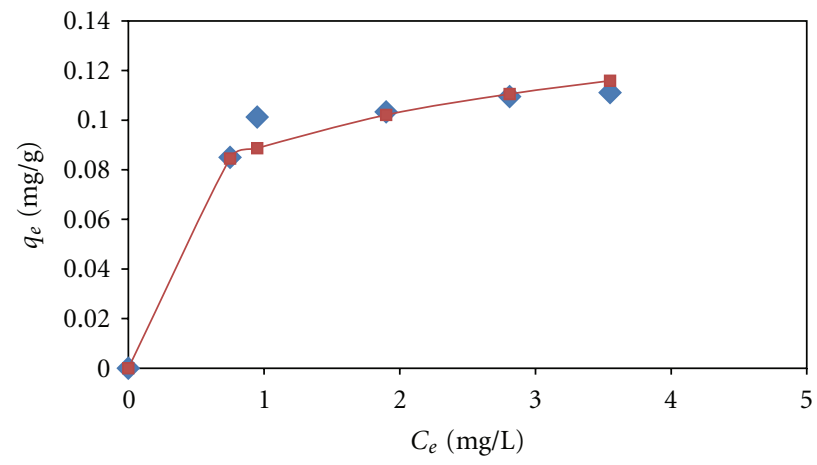

Experimental

-- Theoretical (Langmuir-Freundlich)

FIgURE 17: Adsorption isotherm for phosphorus onto ODS $\left(C_{o}=\right.$ $5 \mathrm{mg} / \mathrm{L}, \mathrm{pH}=6$, Temp. $=25^{\circ} \mathrm{C}$ ).

\subsection{Fixed Bed Experiments}

4.3.1. Effect of Initial Concentration. Experimental data for adsorption of phosphorus onto ODS at flow rate of $6 \mathrm{~L} / \mathrm{hr}$, bed depth of $0.25 \mathrm{~m}$, and particle size of $2.36 \mathrm{~mm}$ are shown in Figure 20. It is clear from the breakthrough curves that an increase in the initial concentration makes the breakthrough curves much steeper, which would be anticipated with the basis of the increases in driving force for mass transfer with increases in concentration of solute in solution. The breakpoint was inversely related to the initial concentration; that is, the time required to reach saturation decreases with increasing the inlet solute concentration. This may also be explained by the fact that since the rate of diffusion is controlled by the concentration gradient, it takes a longer contact time to reach saturation for the case of low value of initial solute concentration.

4.3.2. Effect of Particle Size. The breakthrough curves as shown in Figure 21 were obtained for different particle size at constant initial concentration of phosphorus $(10 \mathrm{mg} / \mathrm{L})$, bed depth of oven-dried alum sludge $(0.25 \mathrm{~m})$, and constant flow rate $(6 \mathrm{~L} / \mathrm{hr})$. The experimental results showed that fine 


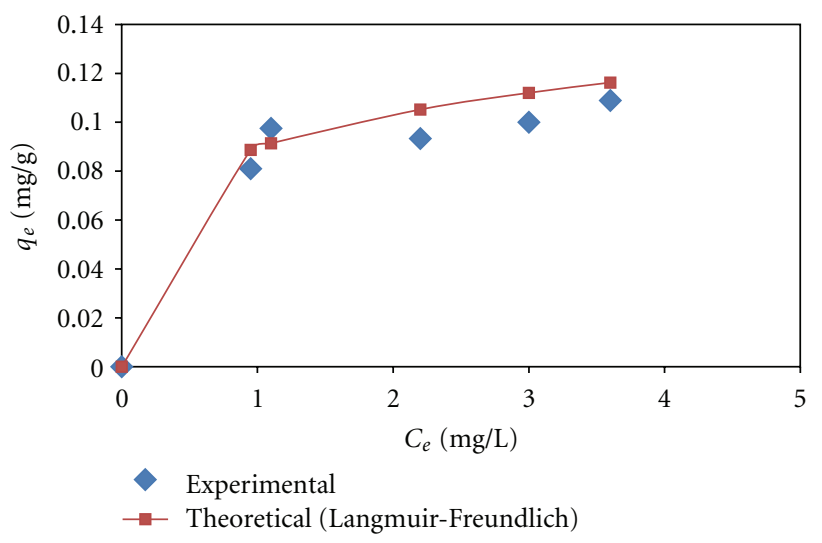

FIGURE 18: Adsorption isotherm for phosphorus onto ODS $\left(C_{o}=\right.$ $\left.5 \mathrm{mg} / \mathrm{L}, \mathrm{pH}=7, \mathrm{Temp} .=25^{\circ} \mathrm{C}\right)$.

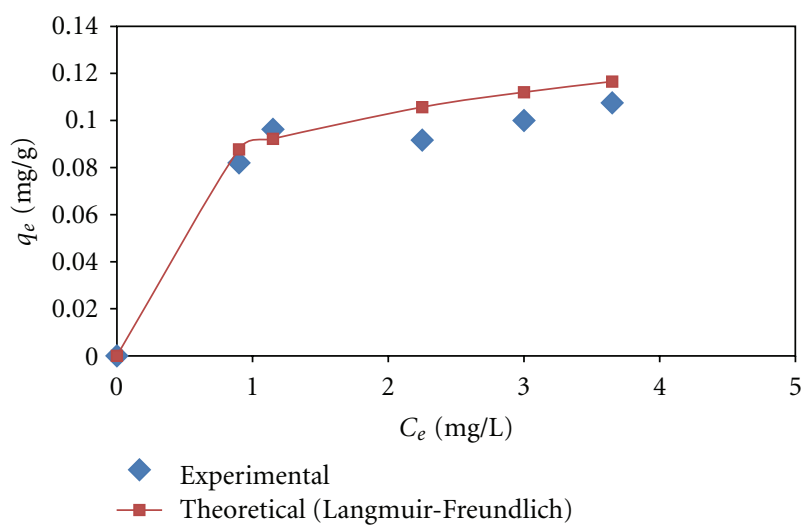

FIgURE 19: Adsorption isotherm for phosphorus onto ODS $\left(C_{o}=\right.$ $5 \mathrm{mg} / \mathrm{L}, \mathrm{pH}=8$, Temp. $=25^{\circ} \mathrm{C}$ ).

TABLE 6: Isotherm parameters for phosphorus adsorption onto ODS with the correlation coefficient.

\begin{tabular}{lcc}
\hline Model & Parameters & Values \\
\hline \multirow{2}{*}{ Langmuir (1) } & $a$, & 2.437878 \\
& $b$, & 0.128524 \\
& Correlation coefficient & 0.977 \\
Freundlich (2) & $K$, & 0.090537 \\
& $n$, & 2.92948 \\
Combination of & Correlation coefficient & 0.9946 \\
Langmuir-Freundlich (3) & $q_{m}$, & 3.675591 \\
& $n$, & 0.025254 \\
& $n$, & 4.793108 \\
& Correlation coefficient & 0.995 \\
\hline
\end{tabular}

particle sizes showed a higher phosphorus removal than coarse particle sizes as illustrated in the figure. This was due to large surface area of fine particles.

4.3.3. Effect of Flow Rate and Bed Depth. In the design of a fixed bed adsorption column, the contact time is the most significant variable, and therefore the bed depth

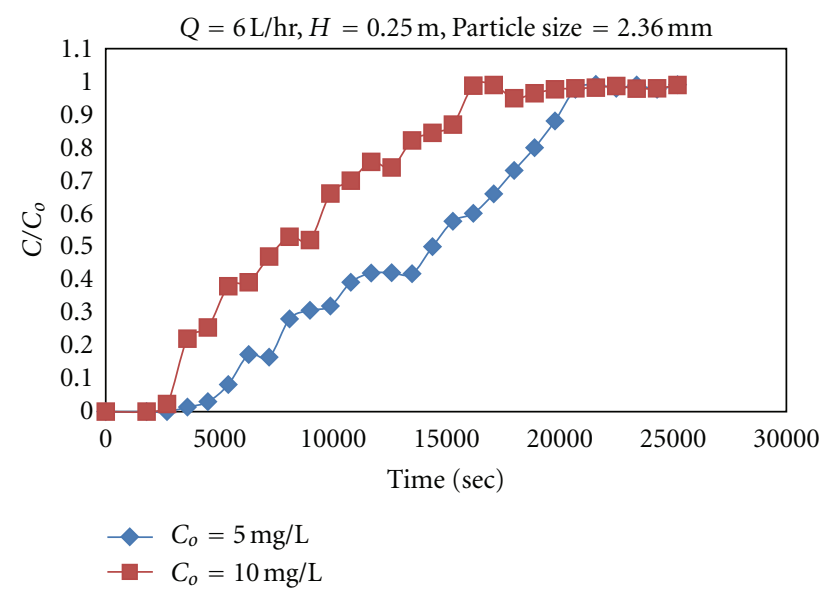

Figure 20: Experimental breakthrough curves for adsorption of phosphorus onto ODS at different initial concentration.

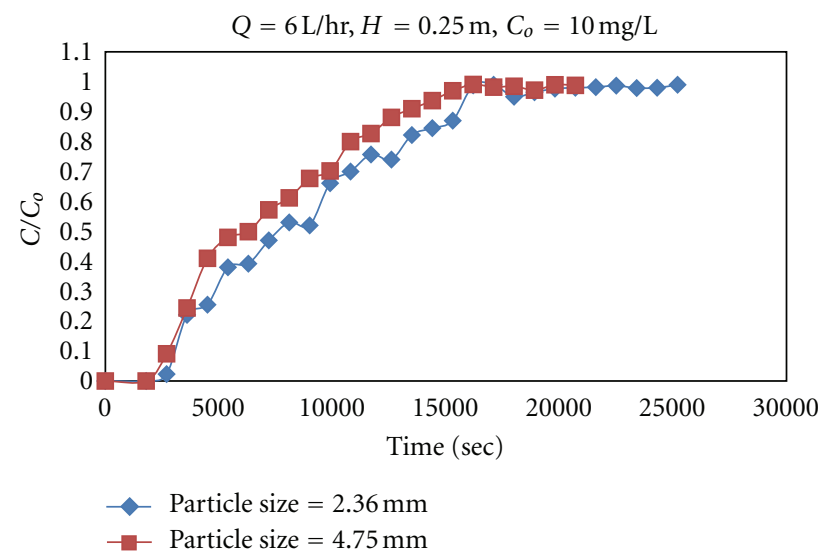

FigURE 21: Experimental breakthrough curves for adsorption of phosphorus onto ODS at different particle size.

and the flow rate are the major design parameter. The effect of varying the volumetric flow rate was investigated. The experimental breakthrough curves are presented in Figure 22 in terms of $C / C_{o}$ versus time at constant initial concentration of phosphorus $(10 \mathrm{mg} / \mathrm{L})$ and particle size $(2.36 \mathrm{~mm})$. Increasing the flow rate may be expected to make reduction of the surface film. Therefore, this will decrease the resistance to mass transfer and increase the mass transfer rate. Also, because the reduction in the surface film is due to the disturbance created when the film of the bed increased resulting from easy passage of the adsorbate molecules through the particles and entering easily to the pores, this decreased contact time between phosphorus and oven-dried alum sludge at high flow rate. The effect of bed depth was investigated for phosphorus adsorption onto oven-dried alum sludge; the experimental breakthrough curves are presented in Figure 23. The breakthrough curves were obtained for different bed depth of oven-dried alum sludge at constant flow rate and constant $\mathrm{P}$ concentration. It is clear that the increase in bed depth increases the breakthrough time and 


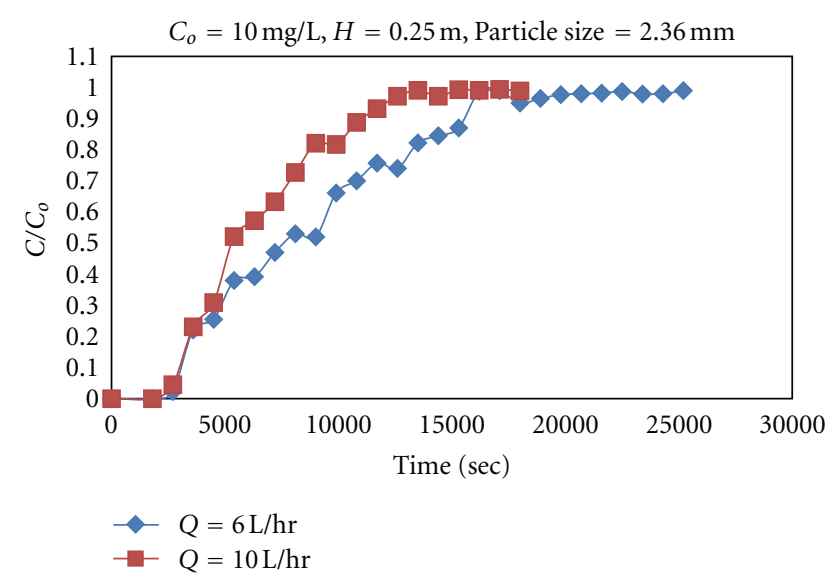

FIGURE 22: Experimental breakthrough curves for adsorption of phosphorus onto ODS at different flow rates.

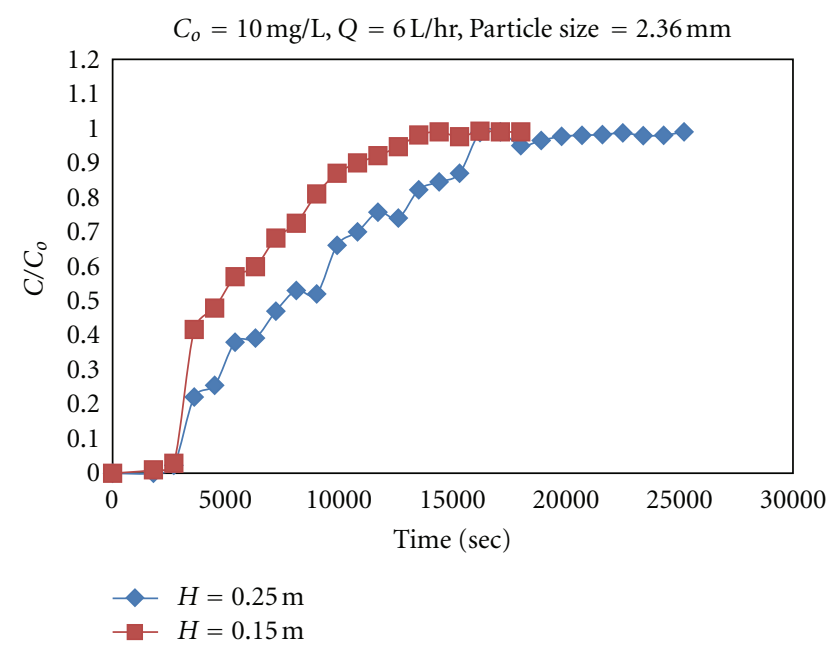

FIGURE 23: Experimental breakthrough curves for adsorption of phosphorus onto ODS at different bed depth.

the residence time of the solute in the column. A comparison is shown in Figure 24, where bed depths are different but residence time was kept constant by changing the flow rate. These results show that increases of fluid velocity had no significant effect. Thus, the residence time in the column is more important than fluid velocity in improving the removal efficiency. The results are obtained, here.

4.3.4. Oven-Dried Alum Sludge Compared to Granular Activated Carbon. The results obtained, here, are presented in Figure 25. Granular-activated carbon (GAC) was used in this study as a reference by which to compare adsorption with oven-dried alum sludge. The results showed that granularactivated carbon had the best phosphorus removal capability due to its higher surface area. These results were on the contrary with the results obtained by Maruf et al., [26] due to higher surface area of alum sludge that was collected from the

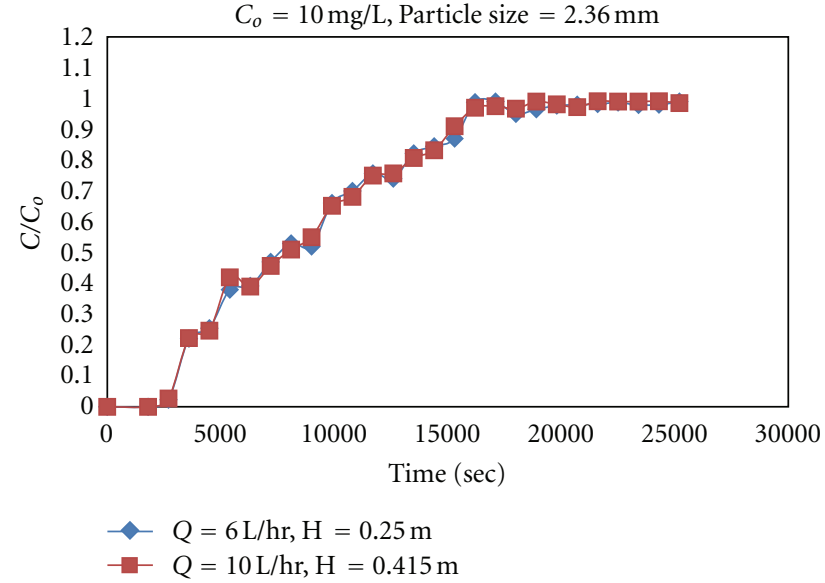

FIgURE 24: Experimental breakthrough curves for adsorption of phosphorus onto ODS at different residence time.

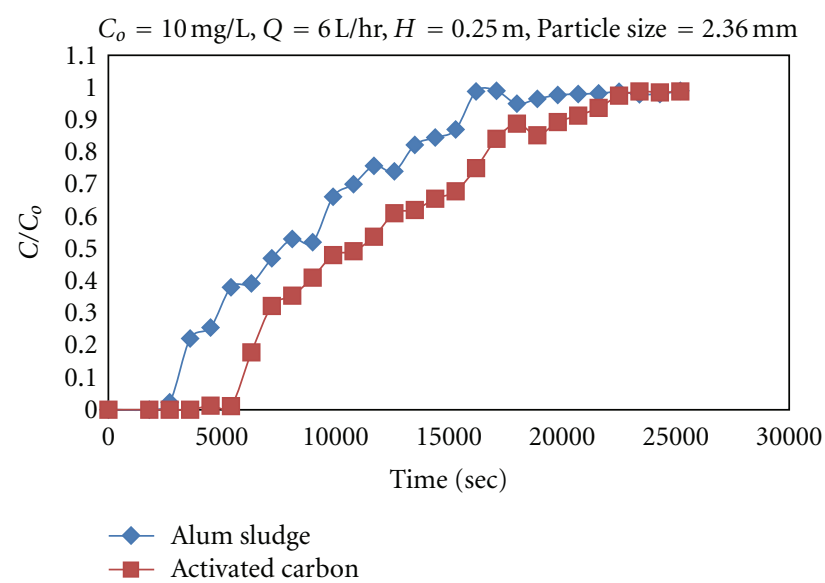

FIGURE 25: Comparison between ODS and granular-activated carbon for phosphorus adsorption.

Lake Major Water Treatment Plant, Halifax Regional Municipality, Canada with respect to granular-activated carbon; also this was probably because of other adsorbates competing with phosphorus in secondary municipal wastewater for adsorption sites.

\section{Conclusions}

The present study has led to the following conclusions.

(1) Oven-dried alum sludge was effective in adsorbing phosphorus from deionized water.

(2) In batch experiment the percent removal of phosphorus increases (85\%) with increasing in the oven-dried alum sludge dose (i.e., $50 \mathrm{~g} / \mathrm{L}$ at deferent $\mathrm{pH}$ ).

(3) Batch kinetics experiments showed that equilibrium time was about 6 days without mechanical mixing.

(4) The results showed that the model (LangmuirFreundlich) gave good fitting for adsorption capacity. 
(5) In fixed bed experiment, the percent removal of phosphorus increases with increasing contact time and adsorbent surface area.

\section{Nomenclature}

$a: \quad$ Langmuir constant $(\mathrm{L} / \mathrm{mg})$

$b$ : Langmuir constant $(\mathrm{mg} / \mathrm{g})$

$C$ : Concentration of solute in solution $(\mathrm{mg} / \mathrm{L})$

$k$ : Freundlich equilibrium constant

$n$ : Freundlich constant

$m$ : Mass of solute adsorbent (g)

$H$ : Bed depth (m)

$\mathrm{pH}$ : Acidity

Q: $\quad$ Flow rate $(\mathrm{L} / \mathrm{hr})$

$q$ : Amount of metal ion adsorbed $(\mathrm{mg} / \mathrm{g})$

$R^{2}$ : Correlation coefficients

$x$ : $\quad$ Mass of solute adsorbed (mg)

$X_{m}$ : Amount of solute adsorbed in forming a complete monolayer (M/M).

\section{Abbreviations}

P: $\quad$ Phosphorus

ODS: Oven-dried alum

MTZ: Mass transfer zone

GAC: Granulated activated carbon

BET: The Brunauer, Emmett, and Teller

QVF: Quality vessels fabrication

ASTM: American society for testing and materials

USEPA: United states environmental protection agency

ID: Inner diameter.

\section{Subscript}

$o:$ Initial

$e$ : Equilibrium

$s$ : Saturation.

\section{References}

[1] Environment Canada, "Proposed approach for wastewater effluent quality," Final Report, Environment Canada, 2000.

[2] USEPA, Environmental Assessment for the Final Effluent Limitations Guidelines, Pretreatment Standards for New and Existing Sources and New Source Performance Standards for the Centralized Waste Treatment, Prepared by Charles Tamulonis, 2000.

[3] Department of Justice, Pollutant Substances Prevention Regulation, Department of Justice, Ottawa, Canada, 2004.

[4] D. Zhao and A. K. Sengupta, "Ultimate removal of phosphate from wastewater using a new class of polymeric ion exchangers," Water Research, vol. 32, no. 5, pp. 1613-1625, 1998.

[5] L. Liberti, D. Petruzzelli, and L. De Florio, "REM NUT ion exhange plus struvite precipitation process," Environmental Technology, vol. 22, no. 11, pp. 1313-1324, 2001.

[6] R. G. Penetra, M. A. P. Reali, E. Foresti, and J. R. Campos, "Post-treatment of effluents from anaerobic reactor treating domestic sewage by dissolved-air flotation," Water Science and Technology, vol. 40, no. 8, pp. 137-143, 1999.
[7] P. Jokela, E. Ihalainen, J. Heinänen, and M. Viitasaari, "Dissolved air flotation treatment of concentrated fish farming wastewaters," Water Science and Technology, vol. 43, no. 8, pp. 115-121, 2001.

[8] K. C. Yu, J. S. Chang, I. P. Chen, D. J. Chang, C. Y. Chang, and S. H. Chen, "The removal of colloid and dissolved phosphorus by coagulation and membrane microfiltration," Journal of Environmental Science and Health A, vol. 35, no. 9, pp. 16031616, 2000.

[9] A. Dietze, R. Gnirß, and U. Wiesmann, "Phosphorus removal with membrane filtration for surface water treatment," Water Science and Technology, vol. 46, no. 4-5, pp. 257-264, 2002.

[10] W. Xie, M. Kondo, and Y. Naito, "Study on phosphorus removal using a new coagulation system," Water Science and Technology, vol. 30, no. 6, pp. 257-262, 1994.

[11] L. Jonsson, E. Plaza, and B. Hultman, "Experiences of nitrogen and phosphorus removal in deep-bed filters in the Stockholm area," Water Science and Technology, vol. 36, no. 1, pp. 183190, 1997.

[12] F. Rogalla, G. Roudon, J. Sibony, and F. Blondeau, "Minimising nuisances by covering compact sewage treatment plants," Water Science and Technology, vol. 25, no. 4-5, pp. 363-374, 1992.

[13] S. Zeghal, N. Puznava, J. P. Subra, and P. Sauvegrain, "Process control for nutrients removal using lamella sedimentation and floating media filtration," Water Science and Technology, vol. 38, no. 3, pp. 227-235, 1998.

[14] D. G. Wareham, K. J. Hall, and D. S. Mavinic, "ORP screening protocol for biological phosphorus removal in sequencing batch reactors," Canadian journal of civil engineering, vol. 22, no. 2, pp. 260-269, 1995.

[15] N. R. Louzeiro, D. S. Mavinic, W. K. Oldham, A. Meisen, and I. S. Gardner, "Methanol-induced biological nutrient removal kinetics in a full-scale sequencing batch reactor," Water Research, vol. 36, no. 11, pp. 2721-2732, 2002.

[16] J. K. Park, J. Wang, and G. Novotny, "Wastewater characteristization for evaluation of biological phosphorus removal," Research Report 174, Department of Natural Resources, Wisconsin, Wis, USA, 1997.

[17] M. I. Aguilar, J. Sáez, M. Lloréns, A. Soler, and J. F. Ortuño, "Nutrient removal and sludge production in the coagulationflocculation process," Water Research, vol. 36, no. 11, pp. 29102919, 2002.

[18] J. G. Kim, J. H. Kim, H. S. Moon, C. M. Chon, and J. S. Ahn, "Removal capacity of water plant alum sludge for phosphorus in aqueous solutions," Chemical Speciation and Bioavailability, vol. 14, no. 1-4, pp. 67-73, 2003.

[19] J. R. Weber and J. Walter, Physicochemical Processes for Water Quality Control, Wiley-Inter Science, New York, NY, USA, 1972.

[20] Metcalf and Eddy, Waste Water Engineering Treatment, Disposal and Reuse, McGrew Hill Book Company, New York, NY, USA, 1979.

[21] W. W. Eckenfelder Jr, Application of Adsorption to Waste Water Treatment, Enviro Press, Nashville, Tenn, USA, 1981.

[22] L. D. Benefield, J. L. Judkins, and B. L. Weanal, Process Chemistry for Water and Wastewater Treatment, Prentice Hall, New Jersey, NJ, USA, 1982.

[23] T. D. Reynolds and P. A. Richards, Unit Operation and Processes in Environmental Engineering, PWS publishing Co, Boston, Mass, USA, 1996.

[24] R. Sips, "Structure of a catalyst surface," Journal of Chemical Physics, vol. 16, pp. 490-495, 1984. 
[25] S. E. Ebrahim, Evaluation of mixture adsorption and glass bed for the removal of phenol and methylene blue from water [Ph.D. thesis], University of Baghdad, Baghdad, Iraq, 2008.

[26] M. Mortula, M. Gibbons, and G. A. Gagnon, "Phosphorus adsorption by naturally-occurring materials and industrial byproducts," Journal of Environmental Engineering and Science, vol. 6, no. 2, pp. 157-164, 2007. 

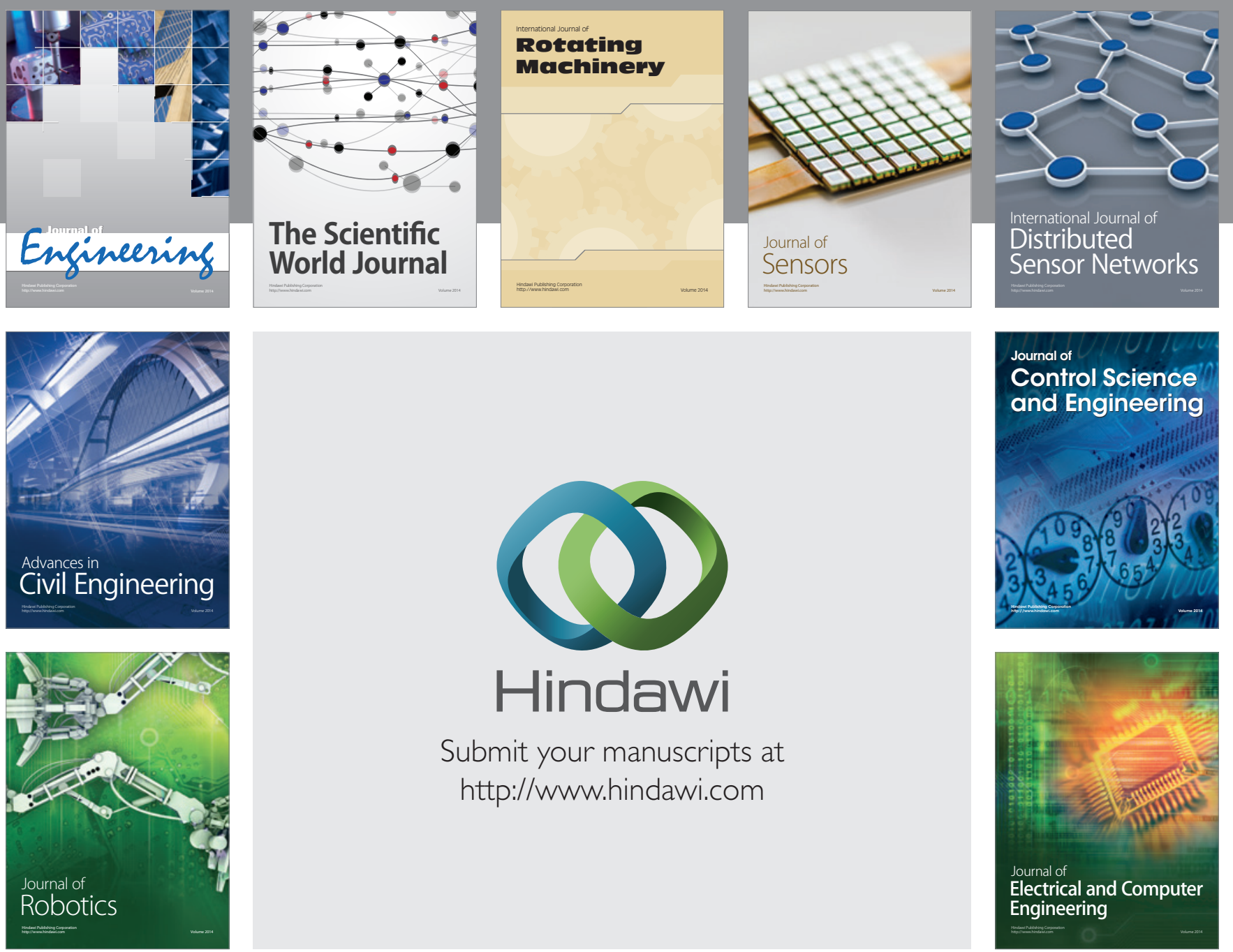

Submit your manuscripts at

http://www.hindawi.com
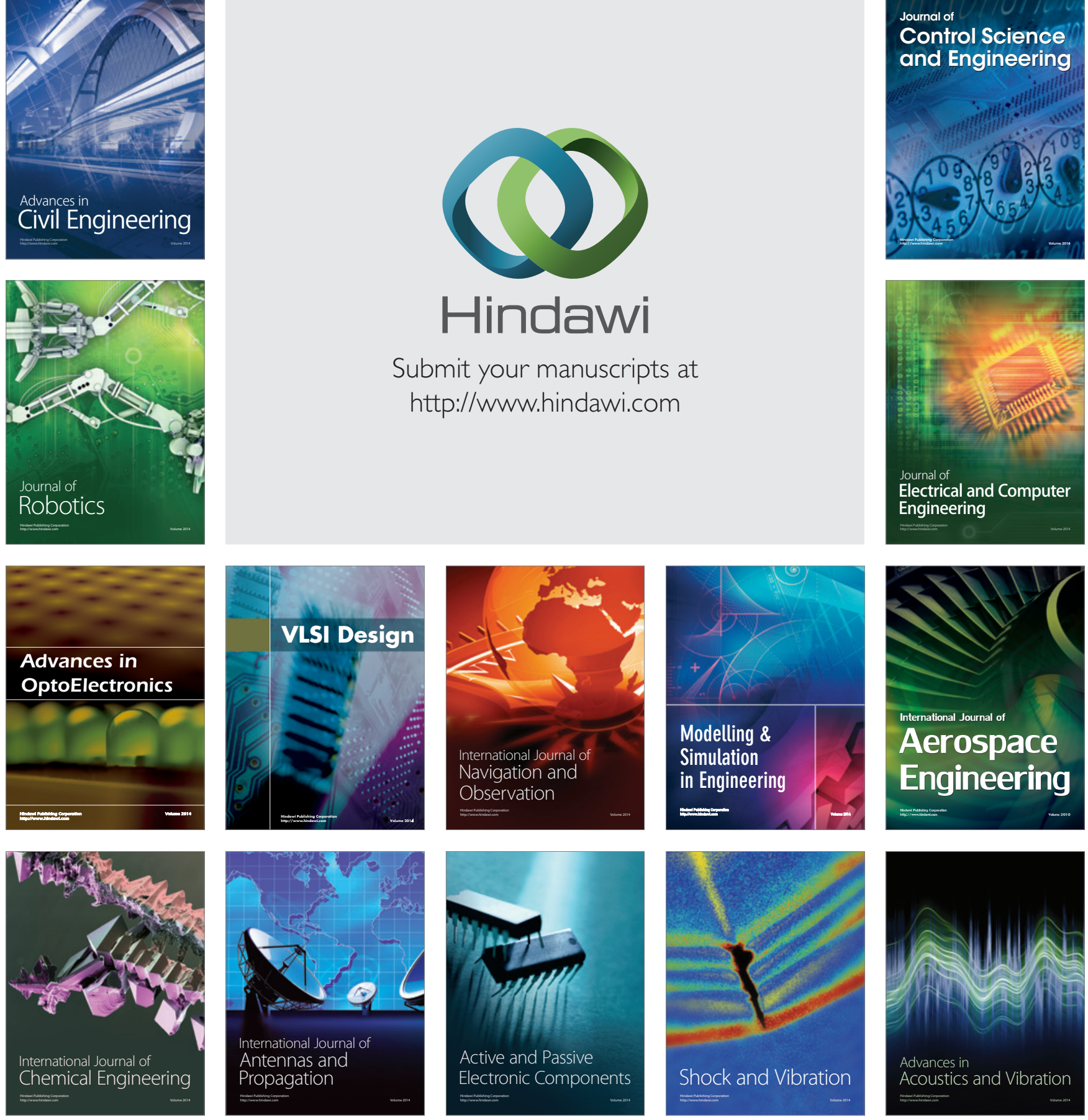